\title{
The marine planktonic cyanobacteria Trichodesmium spp.: photosynthetic rate measurements in the SW Atlantic Ocean
}

\author{
Edward J. Carpenter ${ }^{1}$, Till Roenneberg ${ }^{2}$ \\ ${ }^{1}$ Marine Sciences Research Center, State University of New York, Stony Brook, New York 11794, USA \\ ${ }^{2}$ Institut für Medizinische Psychologie der Universität München, D-80336 München, Germany
}

\begin{abstract}
Rates of photosynthesis of the diazotrophic marine cyanobacteria Trichodesmium spp. were measured with an $\mathrm{O}_{2}$ electrode on 4 cruises to the Bahama Islands and the eastern Caribbean Sea. These phytoplankters had a relatively high light requirement, with $I_{k}$ (irradiance saturation parameter) values ranging from 142 to $295 \mu \mathrm{mol} \mathrm{m} \mathrm{m}^{-2} \mathrm{~s}^{-1}$ photon flux and a compensation irradiance of between 96 and $134 \mu \mathrm{mol} \mathrm{m} \mathrm{m}^{-2} \mathrm{~s}^{-1}$ Thus the compensation depth for Trichodesmium spp. is usually between about 70 and $85 \mathrm{~m}$ in the study area. Trichodesmium spp. had a high dark respiration rate, and this is the major cause of the high compensation irradiance. Because Trichodesmium spp. have gas vesicles, they are buoyant, and the population maxima are typically found at $15 \mathrm{~m}$, approximately $50 \%$ of $I_{0}$ (incident surface irradiance). Thus for most of the day they almost always receive saturating irradiances. The mean $P_{\max }$ values were 44.7 (January-February 1992), 8.29 (September 1992), and 6.45 (SeptemberOctober 1992) $\mathrm{mg} \mathrm{O}_{2} \mathrm{mg}^{-1} \mathrm{chl} \mathrm{a} \mathrm{h}^{-1}$. A calibration with ${ }^{14} \mathrm{C}$ gave a very low photosynthetic quotient $(P Q)$ which averaged 0.46 and 0.61 on 2 cruises. This could have been because of $\mathrm{O}_{2}$ consumption from high RUBISCO oxygenase activity, and this may play a role in protection of nitrogenase from oxygen deactivation. Based on a mean $P Q$ of 0.53 , Trichodesmium spp. carbon turnover times for the 3 cruises were $0.93,7.8$, and $6.13 \mathrm{~d}$, thus indicating relatively rapid growth rates for the population.
\end{abstract}

KEY WORDS: Trichodesmium photosynthesis - Primary productivity - Caribbean Sea phytoplankton Marine planktonic cyanobacteria - Marine diazotrophs $\cdot \mathrm{N}_{2}$ fixation $\cdot$ Photosynthetic quotient

\section{INTRODUCTION}

The cyanobacterium Trichodesmium is one of the most abundant phytoplankters in tropical seas, and photosynthesis and $\mathrm{N}_{2}$ fixation by it contribute a major fraction of the fixed carbon and new nitrogen to surface waters (Carpenter \& Romans 1991). Cells of Trichodesmium contain gas vesicles that render colonies buoyant (Walsby 1978), and this results in population maxima typically near the surface, often at $15 \mathrm{~m}$ depth (Carpenter \& Price 1977). Thus the Trichodesmium population is exposed to high light intensities which range from $100 \%$ irradiance during surface blooms to ca $50 \%$ at its $15 \mathrm{~m}$ population maxima.

It is thus essential, if we are to understand the biology of this organism, to determine how well photosynthesis in Trichodesmium is adapted to the ambient light field.
Kana (1993), using ${ }^{18} \mathrm{O}$ and mass spectrometry, has shown that $T$. thiebautii has a relatively high dark respiration rate, and that high light-dependent Mehler activity may play a role in $\mathrm{O}_{2}$ scavenging and the protection of nitrogenase from $\mathrm{O}_{2}$ deactivation. Furthermore Carpenter et al. (1993) found that dark respiration, and hence the compensation point, was positively correlated with $P_{\max }$ (maximum photosynthetic rate). Both Kana (1992) and Carpenter et al. (1993) found that, as a result of high dark respiration, the compensation point was high relative to most phytoplankters, being 280 and $150 \mathrm{~mol} \mathrm{~m}^{-2} \mathrm{~s}^{-1}$ photon flux, respectively, in their 2 studies. Roenneberg \& Carpenter (1993) found that the compensation point had a diel rhythm which appeared to be under circadian regulation. The compensation point was higher during the day as compared with night values. 
Several measurements of carbon fixation versus irradiance have been made using ${ }^{14} \mathrm{C}$ as a tracer (Carpenter \& Price 1977, McCarthy \& Carpenter 1979, Li et al. 1980, Lewis et al. 1988), and all of these studies indicate that Trichodesmium spp. are adapted to relatively high irradiances as would be experienced at a depth of about $15 \mathrm{~m}$. However, there appear to be very few photosynthesis versus irradiance measurements made over an extensive temporal or geographic range. In view of Trichodesmium's large contribution to $C$ and $\mathrm{N}_{2}$ fixation in tropical seas, it was of interest to determine the efficiency of photosynthesis over a relatively broad area and under different environmental conditions. Thus we took photosynthetic measurements on 4 cruises in a region between the northern Bahama Islands and the Windward Islands in the late winter and early autumn.

\section{METHODS}

Trichodesmium spp. were studied on research cruise 9201 of the RV 'Columbus Iselin' between Miami (Florida, USA) and the Caribbean Sea, from January 17 to February 6, 1992, cruise 9210 between Santo Domingo (Dominican Republic) and Barbados from September 2 to 12, 1992, cruise 9310 from September 14 to October 6, 1993, and on the RV 'Gyre' between Miami and St. Lucia, between May 20 and June 19, 1994 (Fig. 1). Colonies used in the January-February 1992 measurements were collected from the SW Sargasso Sea near the Bahama Islands and the NE Caribbean Sea. Those collected in September 1992 were exclusively from the NE and E Caribbean Sea,

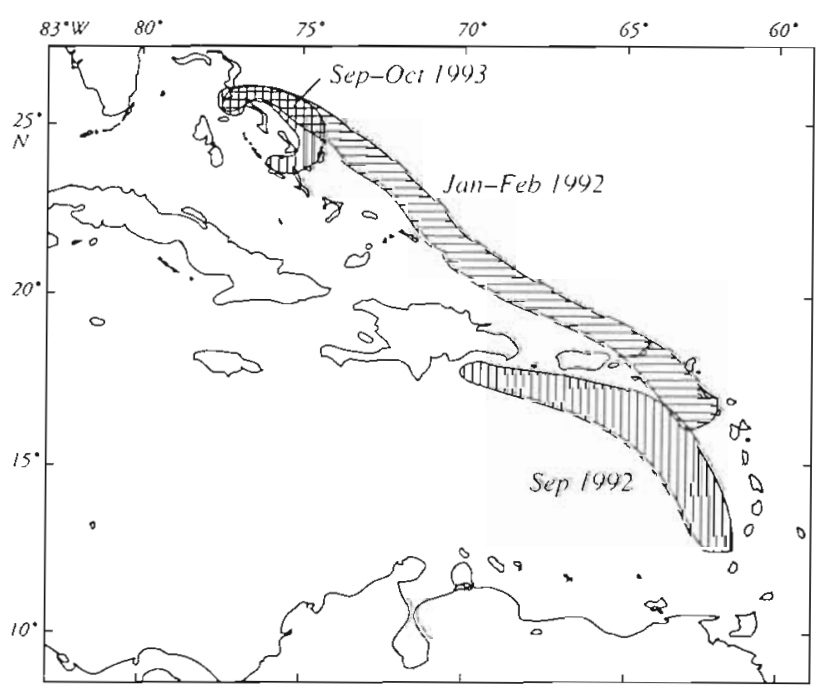

Fig. 1 Study site and locations of research areas during 3 cruises to the Bahama Islands and the eastern Caribbean Sea. $R V$ 'Gyre' cruise area not shown since there was only limited sampling done for a $\mathrm{PQ}$ calibration and in September-October 1993 they were from waters off the Bahama Islands. On the RV 'Gyre' and the 1993 'Iselin' cruises a comparison was made between oxygen production and ${ }^{14} \mathrm{C}$ fixation so that a photosynthetic quotient $(P Q)$ could be calculated. Extinction coefficients $(k)$ were calculated from vertical irradiance profiles collected with a Biospherical Instruments Co. QSP-170B submarine photometer.

Trichodesmium spp. colonies were collected from $15 \mathrm{~m}$ depth with a $1 \mathrm{~m}$ diameter plankton net $(202 \mu \mathrm{m}$ mesh Nitex). They were then rinsed through filtered (GF/F filters which retain particles down to $0.7 \mu \mathrm{m}$ ) seawater, with transfers done with a plastic loop. The collection and handling procedures have been shown to be non-toxic in previous studies (Carpenter et al. 1987). Measurements of $\mathrm{O}_{2}$ production and respiration were made with a Hansatech DW- $1 \mathrm{O}_{2}$ electrode and chamber. Colonies were placed in the plexiglass chamber in $1 \mathrm{ml}$ of filtered $(0.22 \mu \mathrm{m})$ seawater. A Tefloncoated stir bar, immediately above the Clark-style electrode, stirred the water within the chamber. A small plastic disc held $64 \mu \mathrm{m}$ Nitex mesh and separated the colonies from the stir bar, allowing them to remain intact, yet permitting free exchange of water between the electrode and the colonies. In 1993, the mesh basket was not used, as trial measurements indicated that the same results were obtained with intact and dispersed colonies.

The water jacket around the chamber was connected to a circulating water bath which was set at ambient surface seawater temperature. The light source was a Vivitar slide projector with an Osram xenophot HLX $150 \mathrm{~W}$ bulb, and irradiance was regulated with neutral density filters which allowed a photon flux density (PFD) of $10,20,50,105,315,631,1411$ and $1950 \mu \mathrm{mol} \mathrm{m} \mathrm{m}^{-2} \mathrm{~s}^{-1}$ to be received in the electrode chamber in January $1992,5.8,25,69,147,481,647,1211$, and $2240 \mu \mathrm{mol}$ $\mathrm{m}^{-2} \mathrm{~s}^{-1}$ for September 1992, and 20,37, 70, 164, 290, 514, 605,1253 , and $2340 \mu \mathrm{mol} \mathrm{m} \mathrm{m}^{-2} \mathrm{~s}^{-1}$ for September 1993. Irradiance (400 to $700 \mathrm{~nm}$ ) was measured with a Biospherical Instruments Co. QSL-100 light meter From 5 to 10 fresh (within 15 to $30 \mathrm{~min}$ after collection) colonies were placed in the chamber, and rate of oxygen change was first measured in the dark, then $\mathrm{O}_{2}$ change was measured in progression from the lowest to the highest light intensity. A final dark measurement was also made. Generally, rate of change of $\mathrm{O}_{2}$ was measured for 2 min at each intensity, and a complete $P$-I curve could be recorded within 20 to $30 \mathrm{~min}$.

To calculate $P$ - $I$ curves and the parameters $P_{\max } \alpha$ and $I_{k}, O_{2}$ production data were fitted to curves using the formula given by Smith (1936) as follows:

$$
P=P_{\max } \frac{I / I_{k}}{\left[1+\left(I / I_{k}\right)^{2}\right]^{1 / 2}}+R
$$


where $I$ is irradiance, $I_{k}$ (irradiance saturation parameter) is the irradiance at the junction of the initial slope and $P_{\max }$, and $R$ is the rate of dark respiration. The respiration term $(R)$ was added to Smith's equation to yield net photosynthesis.

The differences between sinking and floating colonies of Trichodesmium spp. were compared as regards $P$ - I curves measured with the $\mathrm{O}_{2}$ electrode. After collection with the plankton net, colonies were transferred with plastic bacteriological loops to filtered seawater in a plastic beaker. After 10 min, buoyant or non-buoyant colonies separated, and they could then be isolated with a loop and placed in the electrode chamber. In 1993 and 1994, a comparison of photosynthesis was made between the $\mathrm{O}_{2}$ electrode and the ${ }^{14} \mathrm{C}$ lightdark bottle method. For the latter measurement, $0.2 \mu \mathrm{Ci}$ of ${ }^{14} \mathrm{C}$-bicarbonate was added to a $20 \mathrm{ml}$ glass scintillation vial which held 10 colonies of Trichodesmium spp. Colonies were incubated for $2 \mathrm{~h}$ at midday on deck in an open flowing-seawater incubator in which irradiances were controlled with layers of plastic window screening. Ambient light readings were made with a Biospherical Instruments Co. QSL-100 light meter at the beginning, midpoint, and end of the incubation.

Colonies were filtered onto $25 \mathrm{~mm}$ diameter $0.45 \mu \mathrm{m}$ pore-size Millipore filters, rinsed with filtered seawater and suspended in Ecolume scintillation cocktail, and radioactivity was then counted on ship. Chlorophyll content was determined by withdrawing colonies after $\mathrm{O}_{2}$ measurements and filtering them onto a GFC glassfiber filter which was placed in $6 \mathrm{ml}$ of methanol overnight in a freezer. Chlorophyll a (chl a) fluorescence was measured with a Turner 111 fluorometer, and phaeopigments were subtracted after measurement of the acidified sample.

\section{RESULTS}

\section{January 1992}

A total of $22 P$-I curves collected for Trichodesmium spp. colonies over a $15 \mathrm{~d}$ period indicated a very photosynthetically active population, having a mean $P_{\max }$ of $44(\mathrm{SD}=21.3) \mathrm{mg} \mathrm{O}_{2} \mathrm{mg}^{-1} \mathrm{chl} \mathrm{a} \mathrm{h}^{-1}$ (Fig. 2, Table 1). The average $I_{k}$ value was $295 \mu \mathrm{mol} \mathrm{m} \mathrm{m}^{-2} \mathrm{~s}^{-1}$, and the irradiance compensation point, $C$ (where $P=$ R) was $134 \mu \mathrm{mol} \mathrm{m} \mathrm{m}^{-2} \mathrm{~s}^{-1}$. Water temperature during this cruise ranged from 24.5 to $26.5^{\circ} \mathrm{C}$.

\section{September 1992}

In the eastern Caribbean Sea in autumn, $P_{\max }$ was lower than that in spring, and $46 P$-I curves averaged

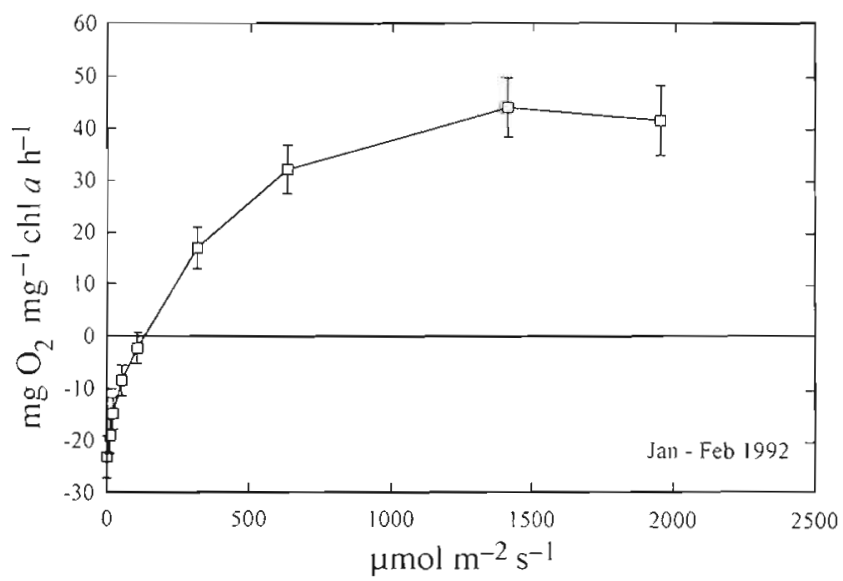

Fig. 2. Trichodesmium spp. Photosynthesis vs irradiance in January-February 1992

$8.28(\mathrm{SD}=3.99) \mathrm{mg} \mathrm{O} \mathrm{O}^{-1} \mathrm{chl} \mathrm{a} \mathrm{h}^{-1}, I_{k}$ averaged $142 \mu \mathrm{mol} \mathrm{m} \mathrm{m}^{-2} \mathrm{~s}^{-1}$, and $C$ was $96 \mu \mathrm{mol} \mathrm{m} \mathrm{m}^{-2} \mathrm{~s}^{-1}$ (Fig. 3, Table 1). Surface water was warmer than in January, ranging from 28.3 to $29.3^{\circ} \mathrm{C}$.

\section{September-October 1993}

The $P$-I values in the Bahamas in autumn were similar to those observed in the eastern Caribbean in the previous autumn (Fig. 4). $P_{\max }$ averaged 6.45 (SD $=2.72) \mathrm{mg} \mathrm{O}_{2} \mathrm{mg}^{-1} \mathrm{chl} \mathrm{a} \mathrm{h}-1, C$ was $130 \mu \mathrm{mol} \mathrm{m} \mathrm{m}^{-2} \mathrm{~s}^{-1}$, while $I_{k}$ was higher than that in 1992 , being $285 \mu \mathrm{mol}$ $\mathrm{m}^{-2} \mathrm{~s}^{-1}$. Water temperature was from 28.5 to $29.7^{\circ} \mathrm{C}$.

Comparisons made between sinking and floating colonies in the autumn of 1993 indicated no measurable differences existed between $P$ - $I$ characteristics (Fig. 5). $P_{\max }$ averaged 6.70 and $6.27 \mathrm{mg} \mathrm{O}_{2} \mathrm{mg}^{-1} \mathrm{chl} \mathrm{a}$ $h^{-1}$, and $\alpha$ averaged 0.017 and 0.021 , for floaters and sinkers, respectively.

Table 1. Photosynthetic parameters for Trichodesmium spp $P_{\max }$ and $R$ are in $\mathrm{mg} \mathrm{O}_{2} \mathrm{mg}^{-1} \mathrm{chl} \mathrm{a} \mathrm{h} \mathrm{h}^{-1} I_{k}$ in $\mu \mathrm{mol} \mathrm{m} \mathrm{m}^{-2} \mathrm{~s}^{-1}$, and $\alpha$ is the initial slope of the $P$-I curve. Light compensation point $(C)$ is in $\mu \mathrm{mol} \mathrm{m} \mathrm{m}^{-2} \mathrm{~s}^{-1}$ Water temperature and light extinction coefficients $(k)$ are also shown, as are the number of $P$-I curves (n)

\begin{tabular}{|c|c|c|c|}
\hline Cruise & Cl9201 & CI9210 & C19310 \\
\hline Time & $\begin{array}{c}\text { Jan-Feb } 1992 \\
22\end{array}$ & $\begin{array}{c}\text { Sep } 1992 \\
46\end{array}$ & $\begin{array}{c}\text { Sep-Oct } 1993 \\
58\end{array}$ \\
\hline$P_{\max }$ & 44.7 & 8.29 & 6.45 \\
\hline$R$ & 17.6 & 4.93 & 2.41 \\
\hline$C$ & 134 & 96 & 130 \\
\hline$I_{k}$ & 295 & 142 & 285 \\
\hline$\alpha$ & 0.137 & 0.055 & 0.019 \\
\hline Temp. $\left({ }^{\circ} \mathrm{C}\right)$ & $24.5-26.5$ & $28.3-29.3$ & $28.5-29.7$ \\
\hline$k$ & 0.049 & 0.065 & 0.032 \\
\hline
\end{tabular}




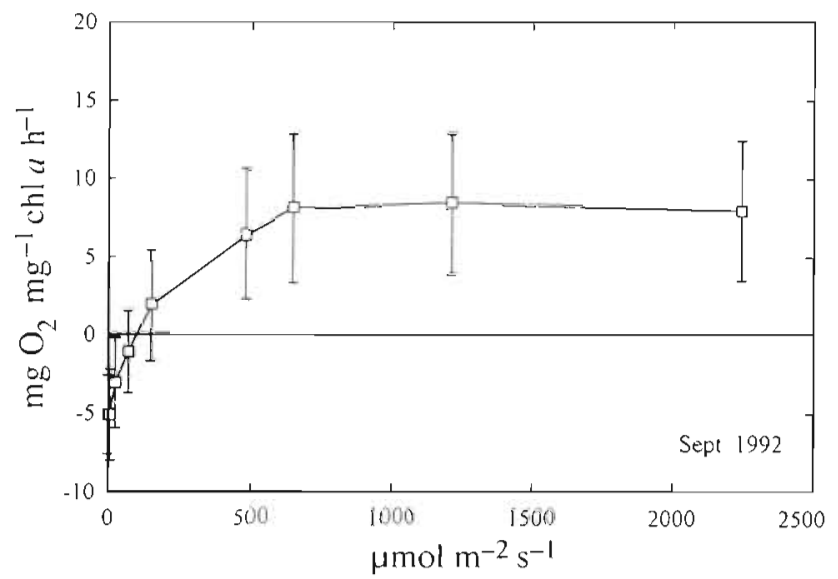

Fig. 3. Trichodesmium spp. Photosynthesis vs irradiance in September 1992

Primary productivity as measured with the $\mathrm{O}_{2}$ electrode and the ${ }^{14} \mathrm{C}$ technique were measured simultaneously on $3 \mathrm{~d}$ in October 1993 and the mean $P Q$ at saturating irradiances was $0.46(\mathrm{SD}=0.14, \mathrm{n}=3)$. In 1994, there was more replication, and comparisons were made over $8 \mathrm{~d}$, giving a mean $P Q$ of $0.61(\mathrm{SD}=$ $0.29, \mathrm{n}=8$ ). Light extinction coefficients $(k)$ ranged from 0.032 in September 1993 to 0.065 in August 1992 (Table 1).

\section{DISCUSSION}

Photosynthetic parameters indicate that Trichodesmium spp. require a relatively high light environment, as they have a high respiratory rate, compensation point, and $I_{k}$ value. However, because of the buoyancy provided by gas vesicles, the population is well adapted to its environment and can remain at or near

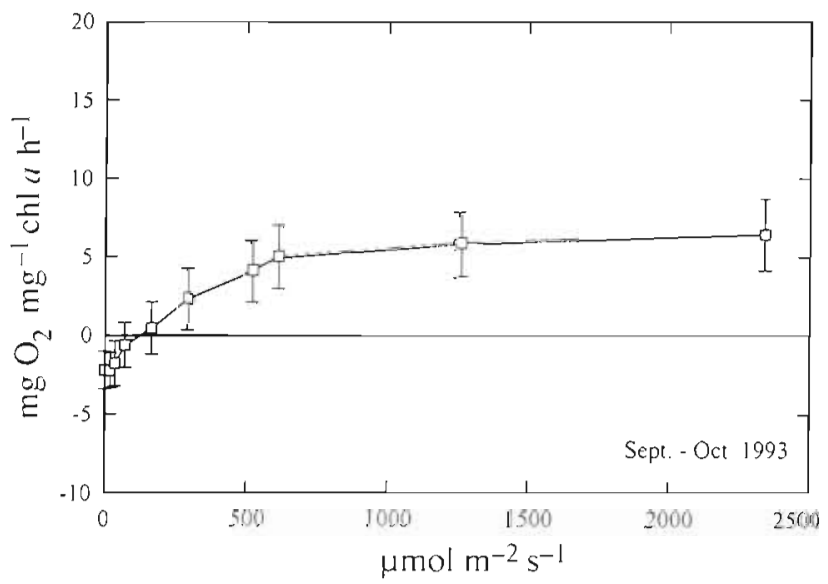

Fig. 4. Trichodesmium spp. Photosynthesis vs irradiance in September-October 1993

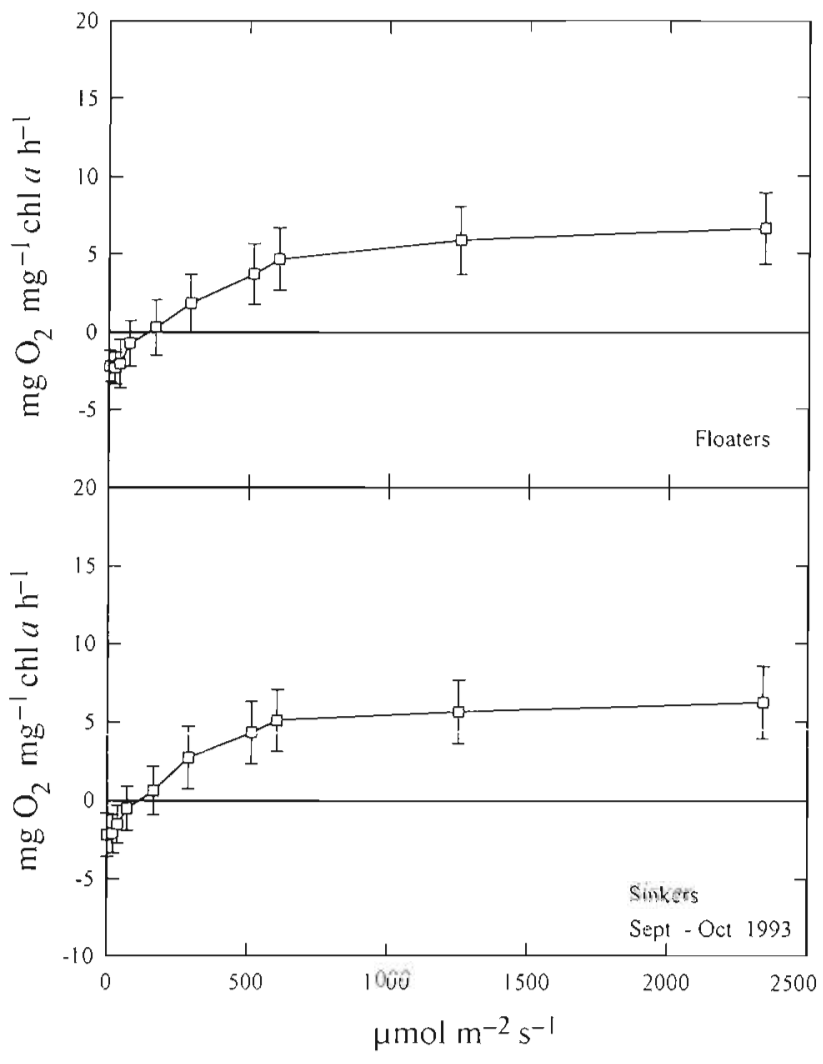

Fig. 5. Trichodesmium spp. Photosynthesis vs irradiance in floating and sinking colonies

the surface (Carpenter \& Price 1977) where there is exposure to high irradiances. The $50 \%$ ambient light value in the waters studied is usually at about $15 \mathrm{~m}$ depth, thus midday irradiances from about 1000 to $1250 \mu \mathrm{mol} \mathrm{m} \mathrm{m}^{-2} \mathrm{~s}^{-1}$ were present at this depth. From the measured extinction coefficients (Table 1) and assuming a sea surface irradiance of $2500 \mu \mathrm{mol} \mathrm{m} \mathrm{m}^{-2} \mathrm{~s}^{-1}$, the calculated light at $15 \mathrm{~m}$ depth was 1120,943 , and $1546 \mu \mathrm{mol} \mathrm{m} \mathrm{m}^{-2} \mathrm{~s}^{-1}$ for January 1992, September 1992, and September 1993, respectively. Irradiance values this high insured that the population was well within the maximal range of photosynthesis for most of the

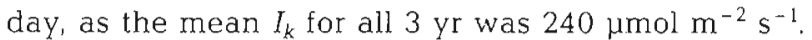
In comparison, most marine phytoplankton have $I_{k}$ values which fall within the range of 50 to $120 \mu \mathrm{mol}$ $\mathrm{m}^{-2} \mathrm{~s}^{-1}$ (Harris 1980). However some phytoplankton may equal or exceed the values measured for Trichodesmium spp. Near surface water (upper $20 \mathrm{~m}$ ) phytoplankton from the equatorial Pacific had $I_{k}$ values which ranged from about 150 to $450 \mu \mathrm{mol} \mathrm{m} \mathrm{m}^{-2} \mathrm{~s}^{-1}$ (Cullen et al. 1992). In a study of 2 diatom and 2 dinoflagellate species, mean $I_{k}$ values were $190 \mu \mathrm{mol}$ $\mathrm{m}^{-2} \mathrm{~s}^{-1}$ for the diatoms and 200 and $260 \mu \mathrm{mol} \mathrm{m} \mathrm{m}^{-2} \mathrm{~s}^{-1}$ for the dinoflagellates (Chan 1980). Picoplankton cells from the deep-water chl a maximum typically have low 
$I_{k}$ values (Joint 1986), but picoplankters are capable of adapting to higher irradiances when near the surface. For example, in the NW Atlantic Ocean, the picoplankton $I_{k}$ was about $132 \mu \mathrm{mol} \mathrm{m} \mathrm{m}^{-2} \mathrm{~s}^{-1}$ at the surface, but at the same station it was $<10 \mu \mathrm{mol} \mathrm{m} \mathrm{m}^{-2} \mathrm{~s}^{-1}$ in the chl a maximum (ca $1 \%$ of $I_{0}$ ). In contrast, the $I_{k}$ of the larger $(>5 \mu \mathrm{m})$ phytoplankton community was $480 \mu \mathrm{mol} \mathrm{m} \mathrm{m}^{-2} \mathrm{~s}^{-1}$ (Prezelin et al. 1986). It is apparent from this research and also laboratory studies that the abundant picoplanktonic cyanobacterium Synechococcus can adapt to a broad range of irradiances (Kana \& Glibert $1987 \mathrm{a}, \mathrm{b})$. In comparison. Trichodesmium has an $I_{k}$ more typical of phytoplankton exposed to surface irradiances.

The compensation irradiances ranged from about 95 to $135 \mu \mathrm{mol} \mathrm{m}{ }^{-2} \mathrm{~s}^{-2}$ photon flux. A typical extinction coefficient $(k)$ in the relatively clear water of the area studied would be about 0.035 , and thus the compensation depth for Trichodesmium would be between about 70 and $85 \mathrm{~m}$.

The light field experienced by the Trichodesmium population is continually changing through the day due to vertical migrations of colonies. Villareal \& Carpenter (1990) have observed buoyancy changes for this cyanobacterium due to carbohydrate ballasting and respiration. Using freshly collected colonies, buoyancy reversals were observed within $2 \mathrm{~h}$ when held in either light or darkness. These reversals tended to follow a diel pattern, with the population predominately sinking during the day, and rising at night. However, at any one time and depth in near surface (upper $25 \mathrm{~m}$ ) waters, there is always a mix of sinkers and floaters, depending on the past light history of the colony. In addition to constantly changing the light field of the organism, buoyancy reversals also prevent the colony from depleting the nutrient field immediately surrounding it. Depth distributions have shown, however, that the population maxima typically remain between about $15 \mathrm{~m}$ and the surface (Carpenter \& Price 1977), and thus at irradiances which allow maximal photosynthesis.

Calculated $P Q$ s indicate strikingly low values for Trichodesmium spp. Mean ratios of moles $\mathrm{O}_{2}$ : moles $\mathrm{C}$ at saturating irradiances were 0.46 for the autumn 1993 cruise and 0.61 for spring 1994, considerably lower than the ratio of 1.2 which is commonly accepted as typical for most phytoplankters. For example, for a diatom, a raphidophyte, and a dinoflagellate, $P Q \mathrm{~s}$ ranged from 1.0 to 1.35 (Langdon 1987). It would intuitively seem impossible to have a $P Q$ of less than 1 ; however, a possible explanation for this is the fact that Trichodesmium has high photorespiratory activity and RUBISCO functions predominately as an oxygenase at midday. Geider \& Osborne (1992) note that PQs of less than 1 can result from high photorespiratory
(RUBISCO oxygenase) activity. Siddiqui et al. (1992) found that nitrogenase and RUBISCO were both located in the same cells in Trichodesmium and they hypothesized that RUBISCO oxygenase activity could act to scavenge $\mathrm{O}_{2}$ and protect the nitrogenase from $\mathrm{O}_{2}$ deactivation. In fact, Li et al. (1980) observed a decrease in carboxylase activity in midday at high irradiances for $T$. thiebautii collected in the Caribbean Sea. The low $P Q$ observed in our study would suggest that this is happening, and it is possible that this is useful in the protection of nitrogenase from $\mathrm{O}_{2}$ deactivation.

Compensation irradiances ranged from 96 to $134 \mu \mathrm{mol}$ $\mathrm{m}^{-2} \mathrm{~s}^{-1}$, and these relatively high values may have resulted from high respiration rates in Trichodesmium spp. Kana (1993) found significant dark respiration, which, in the light, averaged $23 \%$ (13 to $46 \%$ range) of the maximum gross $\mathrm{O}_{2}$ evolution in $T$. thiebautii. Similar values were observed by Falkowski \& Owens (1978) for 6 species of eukaryotic marine phytoplankton, and they noted that dark respiration accounted for about $25 \%$ of gross photosynthesis.

Calculations of carbon turnover times from $\mathrm{O}_{2}$ electrode measurements suggest that the population is growing relatively rapidly. Using the $P_{\max }$ from Table 1, a $P Q\left(\mathrm{~mol} \mathrm{O}_{2}: \mathrm{mol} \mathrm{CO}_{2}\right)$ of 0.53 (mean of $P Q$ in 1993 and 1994), an average of $50 \mathrm{ng}$ chl a colony ${ }^{-1}$ (Carpenter 1983), an $R Q$ (respiratory quotient) of 1 , and $10 \mathrm{~h}$ of light-saturated photosynthesis and $14 \mathrm{~h}$ of dark respiration ( $R$ from Table 1 ) $\mathrm{d}^{-1}$, mean lightsaturated carbon fixation in January 1992, September 1992 and September-October 1993 averaged 10.8, 1.29, and $1.63 \mu \mathrm{g} \mathrm{C}$ colony ${ }^{-1} \mathrm{~d}^{-1}$. The average $\mathrm{C}$ content per colony is $10 \mu \mathrm{g}(\mathrm{n}=35, \mathrm{SD}=3.5)$ (Carpenter 1983), thus the mean $C$ turnover times of the population were $0.93,7.8$, and $6.13 \mathrm{~d}$ for the 3 cruises. These doubling times are similar to most measurements made in the study area. The mean Trichodesmium spp. carbon doubling time noted by Carpenter \& Price (1977) in the central Caribbean was $11.6 \mathrm{~d}$, and Li et al. (1980), using the ${ }^{14} \mathrm{C}$ light-dark bottle method with $T$. theibautii in the eastern Caribbean Sea, calculated a carbon turnover time of $18 \mathrm{~d}$. The authors concluded from enzymatic ratios that the populations were for the most part not healthy. Thus from the literature it would appear that Trichodesmium spp. generally have a doubling time of between about 1 and $20 \mathrm{~d}$ in the Caribbean/Bahamas area.

The marked difference in photosynthetic rates between late winter and early autumn sampling times is difficult to understand. Water temperatures were higher in the autumn, 28.3 to $29.7^{\circ} \mathrm{C}$, as compared with 24.5 to $26.5^{\circ} \mathrm{C}$ in the winter, so it is doubtful that this would be the cause of the different $C$ fixation rates. It is possible that colonies were seasonally limited in an 
essential nutrient such as iron (Martin \& Fitzwater 1988). Trichodesmium has a high iron requirement since this element is needed for synthesis of nitrogenase (Rueter 1988, Rueter et al. 1992). The major fraction of the iron entering the tropical Atlantic Ocean originates as dust from the Sahara Desert. The dust plume shifts with the season, and primarily extends southwest toward Brazil in the winter and due west toward the Caribbean Sea and Bahama Islands in summer (Pye 1987). However, one would expect less iron in the study area during the late winter when photosynthetic rates were highest, and thus it is difficult to associate iron with the higher photosynthetic capacity at that time.

In conclusion, it appears that Trichodesmium spp. have both a high light requirement and a high respiration rate. With the buoyancy capacity provided by its gas vesicles, the population can remain near the surface, and this allows the population to photosynthesize at maximal capacity under typical conditions in its natural habitat.

Acknowledgements. We thank Barbara Dorf, Andrew Parrella, and Samantha Woods for technical support. Ajit Subramaniam kindly supplied extinction coefficients. We are grateful to Todd Kana and Douglas G. Capone for insights and the US NSF (OCE 9015606 and OCE 9317738) and the Deutsche Forschungsgemeinschaft (Ro 656/2) for support of this research. This is contribution 991 from the Marine Sciences Research Center

\section{LITERATURE CITED}

Carpenter, E. J. (1983). Physiology and ecology of marine planktonic Oscillatoria (Trichodesmium). Mar. Biol. Lett. 4: $69-85$

Carpenter, E. J., O'Neil, J. M., Dawson, R., Capone, D. G., Siddiqui, P. J. A., Roenneberg, T., Bergman, B. (1993). The tropical diazotrophic phytoplankter Trichodesmium: biclogical characteristics of two common species. Mar. Ecol. Prog. Ser. 95: 295-304

Carpenter, E. J., Price, C. C. (1977). Nitrogen fixation, distribution, and production of Oscillatoria (Trichodesmium) spp. in the Western Sargasso and Caribbean Seas. Limnol. Oceanogr. 22: 60-72

Carpenter, E. J., Romans, K. (1991). Major role of the cyanobacterium Trichodesmium in nutrient cycling in the North Atlantic Ocean. Science 254: 1356-1358

Carpenter, E. J., Scranton, M. I., Novelli, P. C., Michaels, A. (1987). Validity of $N_{2}$ fixation rate measurements in marine Oscillatoria (Trichodesmium). J. Plankton Res. 9: $1047-1056$

Chan, A. T (1980). Comparative physiological study of marine diatoms and dinoflagelates in relation to irradiance and cell size. II. Relationship between photosynthesis, growth, and carbon/chlorophyll a ratio. J. Phycol. 16: $428-432$

Cullen, J. J., Lewis, M. R., Davis, C. O., Barber, R. T (1992). Photosynthetic characteristics and estimated growth rates indicate grazing is the proximate control of primary pro- ductivity in the equatorial Pacific. J. geophys. Res. 97. $639-654$

Falkowski, P. G., Owens, T. G. (1978). Effects of light intensity on photosynthesis and dark respiration in six species of marine phytoplankton. Mar. Biol. 45: 289-295

Geider, R. J., Osborne, B. A. (1992). Algal photosynthesis. Chapman and Hall, New York

Harris, G. P. (1980). The measurement of photosynthesis in natural populations of phytoplankton. In: Morris, I. (ed.) The physiological ecology of phytoplankton. Univ. of California Press, Berkeley, p. 129-187

Joint, I. R. (1986). Physiological ecology of picoplankton in various oceanographic provinces. In: Platt, T., Li, W. K. W. (eds.) Photosynthetic picoplankton. Can. Bull. Fish. Aquat. Sci. 214: $287-309$

Kana, T. M. (1992). Oxygen cycling in cyanobacteria with special reference to oxygen protection in Trichodesmium spp. In: Carpenter, E. J., Capone, D. G., Rueter, J. G. (eds.) Marine pelagic cyanobacteria: Trichodesmium and other diazotrophs. Kluwer Academic Publishers, Dordrecht. p. $29-41$

Kana, T M. (1993). Rapid oxygen cycling in Trichodesmium thiebautii. Limnol. Oceanogr. 38: 18-24

Kana, T. M., Glibert, P. M. (1987a). Effect of irradiances up to $2000 \mu \mathrm{E} \mathrm{m}^{-2} \mathrm{~s}^{-1}$ on marine Synechococcus WH7803-I. Growth, pigmentation, and cell composition. Deep Sea Res. 34: 479-495

Kana, T. M., Glibert, P. M. (1987b). Effect of irradiances up to $2000 \mu \mathrm{E} \mathrm{m}^{-2} \mathrm{~s}^{-1}$ on marine Synechococcus WH7803-1. Photosynthetic responses and mechanisms. Deep Sea Res. 34: $497-516$

Langdon, C. (1987). On the causes of interspecific differences in the growth-irradiance relationship for phytoplankton. Part I. A comparative study of the growth-irradiance relationship of three marine phytoplankton species: Skeletonema costatum, Olisthodiscus luteus and Gonyaulax tamarensis. J. Plankton Res. 9: 459-482

Lewis, M. R., Ulloa, O., Platt, T (1988). Photosynthetic action, absorption, and quantum yield spectra for a natural population of Oscillatoria in the north Atlantic. Limnol Oceanogr. 33: 92-98

Li, W. K. W., Glover, H. E., Morris, I. (1980). Physiology of carbon photoassimilation by Oscillatoria thiebautii in the Caribbean Sea. Limnol. Oceanogr. 25: 447-458

Martin, J. H., Fitzwater, S. E. (1988). Iron deficiency limits phytoplankton growth in the northeast Pacific subarctic Nature 331: $341-343$

McCarthy, J. J., Carpenter, E. J. (1979). Oscillatoria (Trichodesmium) thiebautii (Cyanophyta) in the central North Atlantic Ocean. J. Phycol. 15: 75-82

Prezelin, B. B., Putt, M., Glover, H. E. (1986). Diurnal patterns in photosynthetic capacity and depth dependent photosynthesis-irradiance relationships in Synechococcus spp. and larger phytoplankton in three water masses in the northwest Atlantic Ocean. Mar. Biol. 91: $205-217$

Pye, K. (1987). Aeolian dust and dust deposits. Academic Press, Orlando

Roenneberg, T., Carpenter, E. J. (1993). Daily rhythm of $\mathrm{O}_{2}$-evolution in the cyanobacterium Trichodesmium thiebautii under natural and constant conditions. Mar. Biol. 117: $693-697$

Rueter, J. G. (1988). Iron stimulation of photosynthesis and nitrogen fixation in Anabaena 7120 and Trichodesmium (Cyanophyceae). J. Phycol. 24: 249-254

Rueter, J. G., Hutchins, D. A., Smith, R. W. Unsworth, N. L. (1992). Iron nutrition of Trichodesmium. [n: Carpenter, 
E. J., Capone, D. G., Rueter, J. G. (eds.) Marine pelagic cyanobacteria: Trichodesmium and other diazotrophs. Kluwer, Dordrecht, p. 289-306

Siddiqui, P. J. A., Carpenter, E. J., Bergman, B. (1992). Ultrastructure and immunolocalization of phycobiliproteins and ribulose 1,5-bisphosphate carboxylase/oxygenase in the marine cyanobacterium Trichodesmium thiebautii. J. Phycol. 28: 320-327

This article was submitted to the editor
Smith, E. L. (1936). Photosynthesis in relation to light and carbon dioxide. Proc. natl Acad. Sci. U.S.A. 22: 504-511

Villareal, T. Carpenter, E. J. (1990). Diel buoyancy regulation in the marine diazotrophic cyanobacterium Trichodesmium thiebautii. Limnol. Oceanogr. 35: 1832-1837

Walsby, A. E. (1978). The properties and buoyancy-providing role of gas vacuoles in Trichodesmium Ehrenberg. $\mathrm{Br}$ Phycol. J. 13: 103-116

Manuscript first received: January 7, 1994

Revised version accepted: December 1, 1994 